\title{
Sowing Attributes and Phenological Effects on Productivity of Wheat - A Review
}

\author{
Kousik Nandi, Debasis Mahata*, Soumya Saha, Anwesh Rai \\ and Subhendu Bandyopadhyay
}

Department of Agronomy, Uttar Banga Krishi Viswavidyalaya, Pundibari, Cooch Behar, West Bengal-736165, India

*Corresponding author

\section{Keywords}

Date of Sowing

Triticum aestivum,

Plant spacing,

Germination count

Article Info

Accepted:

24 June 2018

Available Online:

10 July 2018
Wheat being the most widely used staple food throughout the world requires sustainable increment in productivity. Although mechanization in agriculture in developed countries helped in overcoming different adversities, in Indian sub-continent it is not an easy task. Practices associated with wheat sowing i.e. time, seed rate and depth, spacing, seed treatment are of immense importance in achieving a higher yield of the crop by utilizing available material inputs and environmental resources.

\section{Introduction}

Wheat (Triticum aestivum L.) a staple food for two third of the total world population, is cultivated under different environmental conditions ranging from humid to arid, subtropical to temperate zone. It is an important protein containing cereal with high amount of carbohydrates. It is one of the cheapest sources of carbohydrates and its grain is superior to that of rice in nutritional quality and contains approximately protein $12 \%$, fat $1.72 \%$ carbohydrate $69.60 \%$, mineral $27.2 \%$ and much amount of gluten. However, one challenge for global nutrition is to increase grain yield per unit area while maintaining its end use value. Wheat protein is known as 'gluten' is used for making bread, biscuit and pastry products.

Wheat belongs to Poaceae family and prefers cool and dry climate. Generally, wheat is sown in November to ensure optimal crop growth and development. Among the sowing variables responsible for wheat yield are, sowing methods, seed rate, time of sowing and spacing are very important. Plant spacing determines the area available to each plant 
which in turn determines nutrient and moisture availability to the plant. Row spacing determines resource availability and utilization by individual plants in a given species. If the row is too wide, the crop is unable to rapidly shade the inter-row area to capture sunlight and weeds quickly become established. If the row is too narrow, inter-row crop competition results in poorer yields, difficulties in disease and insect control, and greater likelihood of lodging.

The yield of wheat in the farmer field is much lower than that in the research farm. The yield and quality of wheat grain is known to be influenced by several factors such as variety, sowing time, sowing depth, seed rate, water and nutrient management, harvesting time and other agronomic practices. Inappropriate seed rate and improper crop management practice result low grain yield in wheat. Higher seed rate is not only required for Broadcasting method but also resulted in lower plant population

Keeping these above information in view a systematic review of literature is discussed on the following headings.

\section{Effect of different date of sowing in Wheat}

Date of sowing is one of the key factors for higher production as it determines the optimum time of sowing of the crop. An optimum time of sowing enhances the efficiency of a crop by exploiting growth factors in an effective manner. ThoughOptimal planting dates vary by variety, cropping system, and environmental conditions. Planting earlier or later than the optimal planting date can greatly reduce the yield and quality asphotoperiods were disturbed. The early sowing taken more number of days to flowering and there may be a long vegetative lag phase as the crop does not meet appropriate temperature and other climatic requirement. In other hand late sowing cause high number of chaffy seed due to marked rice of temperature during ripening stage. So optimum date of sowing is crucial factor to obtain high yield.

Suleiman et al., (2014) reported that the late sowing not only shortened the vegetative phases but also significantly reduce the yield of wheat and the highest yield were obtained when cultivars were sown between $1^{\text {st }}$ November to $15^{\text {th }}$ November.

Malik et al.(2009) proposed that late sowing decrease germination count $\mathrm{m}^{-2}$, number of grains spike $^{-1}$ and 1000-grain weight and ultimately cause poor yield and also conclude that highest grain yield $\left(3360 \mathrm{Kg} \mathrm{ha}^{-1}\right)$ was recorded when $125 \mathrm{~kg} \mathrm{ha}^{-1}$ was used for sowing on $15^{\text {th }}$ November.

Badruddin et al., (1994) to avoid high temperature and to ensure optimal crop growth wheat is generally sown in November. Late sowing of wheat faces high range of temperature for its reproductive phase and major cause of yield reduction. About $60 \%$ of the wheat is cultivated under late sowing conditions after harvesting of the transplanted aman rice which are extremely affected by abnormal weather condition at the time of harvesting.

\section{Effect of different spacing in Wheat}

Spacing is another significant factor to obtain high yield in wheat. In optimum row spacing plants utilized all available resources more efficiently including light, water, air and nutrients and accumulate higher dry matter. Finally it increase Length of spike, tiller per square meter. Besides this in optimum row spacing the intercultural operation are become easy. Narrow row spacing increase severity of plant disease and pest. So optimum row spacing play an important role in good crop establishment and high yield. 
Ali et al.(2016)reported that when wheat were sown four different row spacing viz. $15 \mathrm{~cm}, 20$ $\mathrm{cm}, 25 \mathrm{~cm}$ and $30 \mathrm{~cm}$ the wheat plants performs better under $15-\mathrm{cm}$ row spacing than all three other row spacing which significant increase in tillers $\mathrm{m}^{-2}$ and accumulated higher biomass and grain yield, The grain yield increase was mainly attributed to more tillers $\mathrm{m}^{-2}$ at $15-\mathrm{cm}$.

Ghafari et al., (2017) reported that number of tillers, dry matter production $\left(\mathrm{gm}^{-2}\right)$, LAI, number of spikes $\mathrm{m}^{-2}$, the grain yield and straw yield were significantly higher with 20 $\mathrm{cm}$ row spacing as compared to $30 \mathrm{~cm}$ row spacing. Although, spike length and spikelets spike $^{-1}$ were significantly greater with $30 \mathrm{~cm}$ row.

Hussainet al., (2003) proposed that the effect of row spacing in Number of grains spike ${ }^{-1}$, spikelets spike $^{-1}$, spike length and harvest index were non-significant and also concluded that the Maximum no of tillers $\mathrm{m}^{-2}$, spikes $\mathrm{m}^{-2}$, Maximum biological yield and grain yield were obtained from $30 \times 30 \mathrm{~cm}^{2}$ row spacing but Maximum 1000 grain weight are recorded at large row spacing i.e. in $60 \mathrm{~cm}$.

\section{Effect of seed rate in wheat}

Appropriate seed rate are most important agronomic management factor in wheat and barley. Delay in sowing and in dry areas where sufficient soil moisture are not adequate, reduces individual plant growth and tiller production so Late seeding dates and dry areas normally require higher seeding rates. Seed rate also varies variety to variety and sowing method. Generally, broadcasting method require high seed than any other sowing method. So correct amount of seed are necessary for good crop stand and establishment.

Ghulam et al., (2014) reported that wheat varieties Viz. Sarsabz, Kiran-95 and TD-1 required $125 \mathrm{~kg}$ ha ${ }^{-1}$ seed for maximum germination, spike length and grains spike-1 and observed that maximum plant population was recorded under seed rate of $150 \mathrm{~kg} \mathrm{ha}^{-1}$ in Kiran-95 variety and highest grain weight spike $^{-1}$ was also noted under seed rate of 100 $\mathrm{kg} \mathrm{ha}^{-1}$ in TD-1 variety.

According to Khan (1996) to obtain higher grain yield the ideal seed rate is $125 \mathrm{~kg} \mathrm{ha}^{-1}$ for wheat.

Somers et al., (2009) reported that the plant vigor and yield were significantly increased when Wheat sown at the seed rate of $150 \mathrm{~kg}$ $\mathrm{ha}^{-1}$ by drilling method and Number of spikes per Plant, 1000-grain weight, number of grains per spike, grain and straw weight per plot are highest where seed rate maintain@ 125 kg ha 1 .

\section{Effect of seed treatment in Wheat}

seed treatments are used alone or in combination to address or prevent a number of pests, diseases and nutrient deficiencies and to enhance plant growth. These include fungicides, insecticides, inoculants, Plant Growth Regulators, fertilizers and fertilizer enhancers. Using treated seeds can produce measurable yield advantages. Depending on the crop conditions and type of treatment, treated seed can help to optimize yields by reducing the seed dormancy potential, Protects seed from seed rot and seedling blights and helping seeds germinate more easily in hostile conditions.

Forouzandeh et al., (2014) reported that five different wheat cultivars viz. Hamoon, Croosbolani, Hirmand, Bam, Kalak, afghan when treated with different bio-fertilizer like Phosphate solubilizing bacteria, Bio-phosphor, Nitroxin, Nitro-kara, and distilled water as control the croosbolani cultivar recorded highest shoot length $(174.38 \mathrm{~mm})$ followed by kalak afghan cultivar $(139.58 \mathrm{~mm})$ and the 
lowest was in hamoon cultivar $(96.41 \mathrm{~mm})$. In interaction between cultivar and bio-fertilizer were obtained the highest shoot fresh weight was related to kalak afghan and phosphate solubilizing bacteria treatment with mean $(0.21 \mathrm{gm})$. The highest levels of shoot dry weight were obtained in bio-phosphor (0.027) and lowest $(0.022)$ in control treatment.

Azam et al., (2005) reported that wheat seed After surface sterilization with $95 \%$ ethanol (1-min rinsing) followed by repeated washings with sterile distilled water, the seed were soaked for $24 \mathrm{~h}$ in water containing $0,25,50$, 100 , or $200 \mu \mathrm{g} \mathrm{ml}^{-1}$ of 2,4-D solution shows delayed or arrested in seed germination. Delay in seed germination was due to decreased metabolism of seed reserves as observed by much lowered respiration rates (loss of CO2). Though, the number of primary roots increased dramatically and this effect was more pronounced at higher concentrations of 2,4-D but the plant showed stunted growth. Scanning electron microscopy of roots exposed to 2,4-D in the growth medium showed a strengthening of stellar system but damaged cells at the surface. Leakage of cellular material from damaged cells caused an increased colonization of roots by bacteria and their subsequent proliferation in the rooting medium.

\section{Effect of depth of sowing in wheat}

Sowing depth significantly influenced the seedling emergence and vigor index. Sowing seed deeper depth delayed $\&$ reduced seedling emergence \& seed production and sometimes cause greater degree of failure in emergence. Plant emerged from lower depth had produced the highest grain yield which was attributed to greater number of spikes per unit area and seeds per spikes. Deeper sowing caused in the number of seminal root but the total root length was significantly reduced. Deep sowing causes unnecessary elongation of stem between the seed and secondary roots. As a result the food reserves of the grain are taxed severely and seedling may even fail to emerge.

Alam et al., (2014) proposed that the effect of sowing depth was very much important on almost all the parameters except spike length. When wheat were sown under different depth viz. $2 \mathrm{~cm}, 4 \mathrm{~cm}, 8 \mathrm{~cm}$ the maximum grain yield obtain on $4 \mathrm{~cm}$ depth(3.88 t ha-1) followed by $2 \mathrm{~cm}(3.75 \mathrm{t} \mathrm{ha-1)}$ and $8 \mathrm{~cm}$ sowing depth (3.62 t ha-1).

Yagmur and Kaydanr (2009) reported that the grain yield and yield component were closely related with coleoptile length. The grain yield was drastically reduced with shorter coleoptiles due to the deep placement of seed. When the wheat seed was sown at different depths viz. 3, 5, 7, $9 \mathrm{~cm}$ the seed sowing at 5 $\mathrm{cm}$ gave better yields than wheat sown at 3,7 and $9 \mathrm{~cm}$ by 19.9, 22.3 and $62.5 \%$, respectively as it had longer coleoptiles.

Ganl and Stobbe (1995) reported that when seeds were planted within a plot deeper than $50 \mathrm{~mm}$, the proportion of infertile plants increased by $152 \%$ where grain yield was reduced by $19 \%$, compared to uniform shallow $(25 \mathrm{~mm})$ planting. The deep seeded plants produced only $20 \%$ of the grain yield per plant of surroundings shallow-seeded plants. The deep seeded plants having few grain-bearing tillers so yield were also less than the shallow seeded plant.

\section{Effect of phenology on different growth stages in wheat}

Phenology is the development of a plant through successive growth stages. It is important for understanding biomass partitioning and stress assessment.Crops at various growth stages require variable level of moisture and temperature for optimum growth. The plants requirement for water, 
nutrient, and $\mathrm{CO}_{2}$ increases with the advancement of crop phenological growth stages which starting from germination. This increased uptake is used to fulfill energy requirements for higher rate of evapotranspiration, photosynthesis, respiration, and development. However, plant can overcome more stress condition in later stages than the earlier growth stages.

Hossain et al., (2013), reported that Plants have limited nutrient uptake capacity and photosynthetic efficiency under heat and drought stress. These stresses can also reduce organ size (leaf, tiller, and spikes) and growth period for various development stages (tillering, jointing, booting, heading, anthesis, and grain filling).

Drought Stress reduced the number of days to complete the different phenological growth stages and it was also reported that, damaging effects of drought stress were minimized when wheat was planted early in the growing season Ihsan et al., (2016).

Akram et al., (2004) reported that drought tension highly increased spikelet unproductivity and decreased 1000-grain weight and economical yield of grain.

The above study of sowing and sowing attribute of wheat leads to conclusion that planting date affected yield and all other plant characteristics. Most of the wheat cultivar performs better if it is sown between $1^{\text {st }}$ weeks of November to $3^{\text {rd }}$ week of November. The row spacing also significantly affected growth and yield of wheat plants. Row spacing 15-20 $\mathrm{cm}$ should be adopted for its contribution towards higher grain yield. Seed rate also effects on winter wheat yield, its components and other agronomic characteristics. Generally, 100-150 kg seed will enough to sown in one ha of area. Seed treatment also gave positive results towards better crop establishment and yield. It reduces the chance of crop failure in adverse and stress condition. Sowing seed at optimum depth gave better germination and the highest grain yield of wheat and these could be achieved by placing seed at $5 \mathrm{~cm}$ sowing depth. The effect of Phenology on growth stage of wheat also significant. All available natural resource help the plant to grow and produced high grain yield. Under high temperature, moisture stress, flooding condition cause severe damage to the crop. Therefore, proper agronomic practice is requiring. That may overcome the adverse condition of atmosphere and soil to a great extent to achieve the higher yield.

\section{References}

Akram, H. Iqbal, MS. Saeed, A. Ali, A. and Nadem, M.A. (2004). Drought tolerance studies of wheat genotypes. Pakistan Journal of Biological Science.71: 90-92.

Alam, M S. Sultana, M S. Hossain, M B. Salahin, M. and Roy, U K. (2014).Effect of sowing depth on the yield of spring wheat. Journal of Environmental Science and Natural Resources. 7(1): 277-280.

Ali, S. Zamir, M S I. Farid, M. Farooq, MA. Rizwan, M. Ahmad, R. and Hannan, F. (2016) Growth and yield response of wheat (Triticum aestivum L.) to tillage and row spacing in maize-wheat cropping system in semi-arid region. Eurasian Journal of Soil Science.5(1): 53 - 61

Azam, F. Lodhi, A. Farooq, S. Harry-O'kuru, R. and Imam, S H. (2005). Seed treatment with phytohormones and crop productivity. iii. physiological/ biochemical changes in germinating seeds and rooting characteristics of Wheat (TriticumaestivumL.) following exposure to 2,4-D.Pakistan Journal of Botany.37(4): 865-874

Badruddin, M. Sauders, DA. Siddique, AB. Hossain, MA. And Ahmed, M O. (1994). Determining yield constraints for wheat production in Bangladesh. International Maize and Wheat Improvement Centre, 
Library. Pp. 265-271.

Forouzandeh, M. Mirshekari S. and Shiri, Y. (2014). Effect of seeds inoculation by plant growth promoting bacteria on seedling growth of five wheat cultivars under greenhouse experiment. Indian Journal of Fundamental and Applied Life Sciences. 4 (S4): 2929-2935

Ganl,Y. and Stobbe, E H. (1995).Effect of variations in seed size and planting depth on emergence, infertile plants, and grain yield of spring wheat. Canadian Journal of Plant Science.75: 565-570

Ghafari, S R. Dass, A. Hamayoun, $H$. Mohammad, Q M. and Omran, A H. (2017). Effect of row spacing on different wheat (Triticum aestivum L.) varieties in semi-arid region of Kandahar. International Journal of Applied Research.3 (7): 93-97

Khan, AM. (1996). Effect of seeding rates and nitrogen levels on growth and yield of wheat. M.Sc. Thesis, Univ. Agri. Faisalabad, Pakistan

Hossain, A. Sarker, M. Saifuzzaman, M. Teixeirada S J. Lozovskaya, M. and Akhter, M. (2013). Evaluation of growth, yield, relative performance and heat Susceptibility of eight wheat (Triticumaestivum L.) genotypes grown under heat stress. International Journal of Plant Production.7:615-636.

Hussain, I. Khan, M A. and Ahmad, K. (2003).Effect of row spacing on the grain yield and the yield component of Wheat (Triticum aestivum L.). Journal of Agronomy, 2: 153-159.
Ihsan, M Z. El-Nakhlawy, F S. Ismail, SM. Fahad, $S$ and Daur, I. (2016). Wheat phenological development and growth studies as affected by drought and late season high temperature stress under arid environment. Frontiers in Plant Science. 7:795. doi: 10.3389/fpls.2016.00795

Malik, A U. Alias, M A. Bukhsh, H A. and Hussain, I. (2009).Effect of seed rates sown on different dates on wheat under agro-ecological conditions of dera ghazi khan. The Journal of Animal \& Plant Sciences.19(3): 126-129

Nizamani, G S. Tunio S. Buriro, U A. and Keerio,MI. (2014).Influence of different seed rates on yield contributing traits in wheat varieties, Journal of Plant Sciences. 2(5): 232-236

Soomro,U A. Rahman,M U. Odhano, E A. Gul S. and Tareen, A Q. (2009).Effects of sowing method and seed rate on growth and yield of Wheat (Triticum aestivum) world, Journal of Agricultural Sciences.5 (2): 159-162.

Suleiman, AA. Nganya, F J.and Ashraf, M A. (2014). Effect of cultivar and sowing date on growth and yield of Wheat (Triticum aestivum L.) in Khartoum, Sudan.Journal of Forest Products and Industries.3(4): 198-203.

Yagmur, M. and Kaydan, D. (2009). The effects of different sowing depth on grain yield and some grain yield components in wheat (Triticum aestivumL.) cultivars under dryland conditions. African Journal of Biotechnology.8(2): 196-201.

\section{How to cite this article:}

Kousik Nandi, Debasis Mahata, Soumya Saha, Anwesh Rai and Subhendu Bandyopadhyay. 2018. Sowing Attributes and Phenological Effects on Productivity of Wheat - A Review. Int.J.Curr.Microbiol.App.Sci. 7(07): 3327-3332. doi: https://doi.org/10.20546/ijcmas.2018.707.387 